\title{
Judecata particulară și vămile văzduhului
}

\section{Iulian NEDELCU}

\begin{abstract}
Every soul immediately after death bear a special court, after which it is sent to either happiness or torment. The Earthly life is the arena in which man decides his fate forever, and after death he cannot do anything about it. The Happiness where souls go after the particular judgment is a continuation of communion with Christ, and tortures are the lack of this communion. The author and the judge is Christ, and the criterion is perseverance of each to get closer to Him by the commandments. On the Air Customs, the soul is judged, and at this judgment he has witnesses, accusers and defenders.
\end{abstract}

Keywords: soul, happiness, sorrows, communion, Christ, angels, devils.

\section{Introducere}

Întreaga existenţă umană este deschisă unei singure posibilităţi, adică ori trăim pe de-a întregul, conştientizând oferta eshatologică, 


\section{Iulian NEDELCU}

ori o refuzăm.

Eshatologia este un piedestal al apogeului creației, partea ultimă a existenţei noastre. „Este partea finală nu în sensul că după ea urmează sfârşitul total al existenţei, ci în sensul că această etapă finală durează veşnic, nemaifiind urmată de nici o altă etapă”'.

Iisus Hristos S-a întrupat, ca să ducă la împlinire planul Tatălui, desăvârşirea naturii umane. Pentru a primi ceea ce Dumnezeu Însuşi a promis ca răsplată tuturor celor ce-I urmează învăţătura, creştinul trebuie să lucreze continuu sufleteşte şi trupeşte. Toată viaţa noastră pământească în Hristos, dacă n-ar fi această fază finală, ar fi zadarnică. „Învierea Ta cea din morţi o slăvim, Hristoase, prin care ai slobozit neamul lui Adam de tirania iadului și ai dăruit lumii ca un Dumnezeu viaţa veşnică și mare milă’’2.

Totodată viaţa pământească dobândeşte un sens, când omul face din ea o călătorie conştientă spre moarte şi spre cele de după ea, ca o ţintă a vieţii. „Cel ce călătoreşte fără ţintă se va osteni în deşert”’3 spune Teodor al Edessei, ceea ce presupune o trăire duhovnicească deosebită, o abandonare a vieţii pământeşti în materialitatea sa şi o îndreptare spre duhul învăţăturii Evangheliei: „Dacă vieţuiţi după trup, veţi muri, iar dacă ucideţi cu Duhul faptele trupului, veţi fi vii”" (Romani, 8, 13).

Dreptatea divină, reflectată în persoana umană, „constă în conştiinţa şi certitudinea omului despre o dreptate inerentă şi absolută, certitudine concretizată prin sacrificiul său, până la anulare de sine, în

\footnotetext{
${ }^{1}$ Pr. Prof. Dr. Dumitru Stăniloae, Teologia Dogmatică Ortodoxă, ed. a II-a, vol. III , Bucureşti, Edit. Institutului Biblic şi de Misiune al Bisericii Ortodoxe Române, 1997, p. 143.

${ }^{2}$ Penticostarul, Sâmbăta în Săptămâna Luminată, la Vecernie, la Doamne strigat-am..., alte Stihiri ale lui Anatolie, glasul al 8-lea, Stihira a II-a , p. 52-53. ${ }^{3}$ Sfântul Maxim Mărturisitorul, Invăţătura despre viaţa morală în 170 de capete, în Filocalia, vol. I, traducere de Pr. Stavr. Dr. D. Stăniloae, Sibiu, Tipografia Arhidiecezană, 1947, p. 12.
} 
serviciul acestei dreptăţi"4.

\section{JUDECATA PARTICULARĂ}

\subsection{Noțiunea de judecată}

Mărturisirea Ortodoxă afirmă că moartea dizolvă forma ființei umane, trupul sau partea materială din om, iar sufletul, după despărțirea de trup, își continuă viața într-o altă lume, pe un alt plan de existență. Această existență este precedată de o judecată.

Această judecată particulară, a fiecărui suflet în parte, are în vedere faptele, vorbele și gândurile omului, care se află scrise în cartea veșniciei, mai exact haina virtuții sau a păcatului, pe care o îmbracă înainte de moarte (starea generală din momentul morții).

„Închipuie-ţi pe un împricinat învinuit şi dovedit de crimă, nu aducând temeiuri de apărare, ci aşternându-se la picioarele judecătorului şi rugându-1. Judecătorul îi va răspunde: Nu pot să fac de la mine nimic. La judecata dreaptă, nu puterea are cuvântul. $\mathrm{Nu}$ te judec eu, faptele tale te judecă; ele te acuză, ele te condamnă. Te judecă legile pe care ca judecător nu le schimb, ci le păzesc. N-aduc nimic de la mine; dimpotrivă, judecata pleacă de la tine şi ajunge tot la tine. Judec după ceea ce aud, nu după ceea ce voiesc. De aceea este adevărată judecata mea, fiindcă nu mă supun voinţei, ci dreptăţii’’5.

Judecata particulară nu este completă (la ea nu participă trupul - de aceea, până la înviere, sufletul suferă sau se bucură doar anticipat și parțial de pedeapsa sau fericirea veșnică) și nici definitivă. „Nu se cuvine să dispreţuim judecata lui Dumnezeu, ci să ne temem

${ }^{4}$ Pr. Prof. Dr. George Remete, Dogmatica Ortodoxă, Alba-Iulia, Edit. Reîntregirea, 2007, p. 146.

${ }^{5}$ Sf. Ambrozie al Milanului, Scrisori, scrisoarea a LXXVII-a, 11, în PSB, vol. 53, pp. 307-308 


\section{Iulian NEDELCU}

chiar dacă răsplata n-ar urma imediat" ${ }^{\prime \prime}$ Judecata Particulară este provizorie, deoarece recompensa sau pedeapsa o va suporta numai sufletul.

\subsection{Realitatea judecății particulare}

Judecata lui Dumnezeu este o realitate, căci

„,̂n afară de judecata lui Hristos nu e decât iadul; judecata Lui dă ocazia celor ce o admit să scape de neființă sau de iad. Adică: Sau există Hristos și o judecată a Lui, şi atunci scapă de neființă sau de iad măcar cei ce cred în El, sau nu există, şi atunci tot ce e persoană e condamnat pieirii sau iadului etern, echivalent cu lipsa oricărui sens"”.

Judecata Particulară este atestată de Sfânta Scriptură, de Sfânta Tradiție și de Sfinții Părinți.

Părintele Stăniloae arată criteriul suprem care se evidențiază prin judecată spunând:

„Judecata divină e necesară pentru precizarea modului vieții eterne a creaturilor. Printr-o astfel de judecată se pune în relief caracterul de persoană al lui Dumnezeu, dar și un interes al Lui pentru oameni. Pe lângă aceasta, se pune în evidență un suprem criteriu al binelui și al răului. Acest criteriu e Dumnezeu Însuși și tot El e și forul de ultimă instanţă al acestui criteriu"s.

Din punct de vedere logic, dacă nu ar exista judecata particulară, înseamnă ori că sufletele decedaților aşteaptă judecata universală într-o stare de somn, sau de așteptare chinuitoare (ceea ce ar fi avantajos

\footnotetext{
${ }^{6}$ Sf. Vasile cel Mare, Regulile morale, Reg. 11, în PSB, vol. 18, p. 112

7Pr. Prof. Dr. Dumitru Stăniloae, Teologia Dogmatică Ortodoxă, vol. III, Bucureşti, Edit. Institutului Biblic şi de Misiune al Bisericii Ortodoxe Române, 1978, p. 281.

${ }^{8}$ Pr. Prof. Dr. Dumitru Stăniloaie, op. cit, p. 259.
} 
numai pentru păcătoși, că li se amână pedeapsa, dar i-ar lipsi pe cei drepți de bucuria comuniunii cu Dumnezeu), ori că sufletele dezvoltă și dincolo de mormânt o activitate morală (învăţătură condamnată odată cu apocatastaza, și care, în plus, 1-ar determina pe om să nu se mai îngrijească de viața sa morală pe pământ) ${ }^{9}$.

\subsection{Autorul și martorii judecății particulare}

Autorul judecății particulare este Mântuitorul Hristos, întrucât „Tatăl nu judecă pe nimeni, ci toată judecata a dat-o Fiului” (Ioan 5, 22). Hristos este autorul judecăţii

„în sensul că din El se revarsă viața și fericirea comuniunii depline peste cei ce au viețuit după pilda Lui şi s-au asemănat cu El, având în ei încă din viața aceasta toată lumina și bucuria comuniunii cu El, iar cei ce nu L-au urmat vor rămâne într-o lipsire definitivă de bucuria acestei comuniuni cu El, Persoana-izvor a toată iubirea dumnezeiască și omenească. Pentru cei dintâi, judecata lui Hristos înseamnă arătarea Lui cea mai evidentă în relația cu ei, împreună cu toate darurile iubirii Lui; pentru cei din urmă - încetarea oricărei încercări a Lui de a Se mai apropia de ei" ${ }^{\prime 10}$.

Dar la judecata particulară, Dumnezeu se foloseşte nu numai de îngeri şi de duhurile rele ca martori sau acuzatori, ci şi de conştiinţa luminată a omului, prezentă în suflet după despărţirea acestuia de trup, după cum scrie Tertulian: „Când prin puterea morţii (sufletul) iese din unirea cu carnea şi prin această ieşire se purifică, atunci scapă, fără îndoială, din închisoarea corpului în loc deschis la lumina sa cea pură şi curată şi în libertate priveşte divinitatea şi s-a ridicat la cunoaşterea adevărului""

${ }^{9}$ Prof. N. Chiţescu, Pr. Prof. Isidor, I. Petruţă, Teologia Dogmatică şi Simbolică, Cluj-Napoca, vol. II, ed. a II-a, 2005, pp. 278-279.

${ }^{10}$ Pr. Prof. Dr. Dumitru Stăniloaie, op. cit, p. 274.

${ }^{11}$ Herma, Păstorul, Pilda I, în Scrierile Părinţilor Apostolici, din col. P.S.B., 


\section{Iulian NEDELCU}

\subsection{Criteriile judecății particulare}

Cununa va fi tot Mântuitorul, iar criteriul după care se va face judecata este efortul sau lipsa de efort manifestate în viaţă de cel judecat de a se apropia de Hristos, urmându-I pilda şi de a intra în comuniune cu El.

Felul diferit în care suntem judecaţi de către Dumnezeu în cele trei momente ale existenţei depinde de starea specifică a naturii omeneşti corespunzătoare fiecăreia dintre aceste stări. Astfel, în viaţa pământească omul este lăsat liber să aleagă între bine şi rău, fără a fi răsplătit sau pedepsit imediat şi deplin în această viaţă. După moarte, sufletul are parte de Judecata particulară, unde el urmează să trăiască în rai sau în iad, după cum a ales mai mult binele sau răul în viaţă. Rugăciunile Bisericii pot încă să mijlocească pentru izbăvirea sufletului în această stare, dacă Dumnezeu poate găsi un punct de sprijin în iubirea dintre el şi semeni pentru salvarea lui ${ }^{12}$. La Judecata de Apoi oamenii din nou întregi sunt cercetaţi de Dumnezeu pentru a se vedea dacă există vreo asemănare a lor cu lisus Hristos pentru a se mântui: sfinţii vor străluci în slavă şi se vor alătura Împărăţiei lui Dumnezeu, iar cei ce nu au nici un punct comun cu dragostea lui Hristos şi diavolii vor urma consecinţele ale alegerii de a se depărta de Dumnezeu, rămânând despărţiţi de El şi resimţind chinul acestei despărţiri de Izvorul vieţii şi al fericiriii ${ }^{13}$.

Între cer și pământ este o legătură nemijlocită. Drepții pot fi duși ușor după moarte în cer, acolo unde este și Hristos (Filip. 1, 23). Cerul e plinătate a existenței, pentru că în el ei se împărtășesc de Cel ce este cu adevărat. Scara pe care putem urca în cer sunt virtuțile,

vol. 1, pp. 267-268.

${ }^{12}$ Pr. Prof. Dr. Ioan Constantinescu, Rugăciunile pentru cei morţi, în „Glasul Bisericii”, an. XXXIV, 1975, nr. 7-8, p. 752.

${ }^{13}$ Cf. Pr. Prof. Dr. Dumitru Stăniloae, Teologia Dogmatică Ortodoxă, ed. a II-a, vol. III , București, Edit. Institutului Biblic şi de Misiune al Bisericii Ortodoxe Române, 1997, pp. 165 ș.u., 286 ș.u. 
formele umane ale însuşirilor lui Dumnezeu. Ele reprezintă un dialog cu Dumnezeu, în care noi chemăm pe Dumnezeu și El răspunde venind.

\section{Vămile Văzduhului}

Învăţătura despre vămile văzduhului se referă la călătoria sufletului după despărţirea de trup și cuprinde ideea că, după moarte, demonii încearcă să găsească motive ca să ducă sufletul celui adormit în iad, în timp ce rugăciunile celor vii ocrotesc sufletul celui adormit, dacă acesta poate fi apărat. Hotărârea finală cu privire la trimiterea sufletului în iad sau aşezarea sa în rai depinde de starea sa în ceasul morţii.

Sfântul Ioan Gură de Aur, descriind ce se întâmplă în ora morţii, învaţă:

„Atunci vom avea trebuinţă de multe rugăciuni, de mulţi care să ne ajute, de multe fapte bune, de multă mijlocire din partea îngerilor, de-a lungul întregii noastre călătorii prin văzduh. Dacă atunci când străbatem o ţară străină sau un oraş necunoscut avem nevoie de călăuză, cu atât mai mult vom avea nevoie de călăuze şi de ajutoare să ne arate calea printre nevăzutele dregătorii şi puteri şi domnii ale văzduhului, care sunt numite persecutori şi vameşi şi perceptori“‘14.

Din punct de vedere teologic, spunea Larchet:

„ne aflăm pe tărâmul unei cronologii simbolice, alta fiind măsura timpului duhovnicesc, nesupus materiei şi repetiţiei [...] Ele nu trebuie însă înţelese după literă, ci simbolic. Rostul lor este mai întâi de toate de a ne face să înţelegem că dincolo e o cu totul altă lume şi o cu totul

${ }^{14}$ Sf. Ioan Gură de Aur, Omilia despre răbdare și recunoștință, care se citește în cadrul slujbelor Bisericii Ortodoxe în cea de-a șaptea duminică a Paștilor și la slujbele de înmormântare. 


\section{Iulian NEDELCU}

altă vieţuire [...] căci acesta este rostul lor, să gătească sufletul pentru călătoria în cealaltă lume și pentru viața ce-l așteaptă acolo"15.

Sfântul Teofan Zăvorâtul scrie că ceea ce demonii cercetează sunt „patimile” şi s-ar putea ca demonii să încerce totodată să ademenească sufletul, folosindu-se de slăbiciunile acestuia.

I. Puhalo ${ }^{16}$ si M. Azkoul ${ }^{17}$ au criticat învățătura despre vămile văzduhului spunând că sufletul și trupul sunt inseparabile și de aceea sufletul nu poate avea o viață a lui, independentă de trup. Sufletul cunoaște trupul și după moarte chiar dacă acesta se descompune în pământ, aşa după cum unele vase de lut de diferite mărimi chiar dacă se sparg și cioburile sunt amestecate, totuși ele sunt recunoscute de cel care aparțin. Trupul și sufletul constituie esența, un om anume.

Învățătura despre vămile văzduhului este o teologumenă, ea n-a făcut obiectul unei definiții dogmatice din partea Bisericii.

În concluzie, vămile sunt mai degrabă „etape ale judecăţii particulare şi Biserica noastră nu le-a perceput nici ca loc, nici ca spaţiu, chiar dacă nelămuririle privitoare la aceste vămi ale văzduhului încă persistă".

După învăţătura Bisericii Ortodoxe, nu trecerea de anumite vămi este prioritară sau scop în sine. Nu există o târguială sau plată în schimb pentru mântuirea sufletului, folosindu-se bani sau alte bunuri date de pomană. Îngerii răi nu se substituie judecăţii particulare pe care o face Dumnezeu, ci comuniunea şi îndumnezeirea omului cu Hristos este ţelul şi destinaţia lui.

\footnotetext{
${ }^{15}$ Jean Claude Larchet, Tradiția ortodoxă despre viața de după moarte, trad. din lb. franceză de Mihaela Bojin, București, Ed. Sophia, 2006, pp. 150-151.

${ }^{16}$ I. Puhalo, The Soul, the Body and the Death, Dewdney, B. C., 1996. The Tale of Elder Basil the New and the Theodora Myth. Study of a Gnostic Document, Dewdney B. C., 1999.

${ }^{17}$ M. Azkoul, The Toll-House Myth. The Neo-Gnosticism of Fr. Seraphim Rose, Dewdney B. C.
} 


\section{Starea sufletelor după judecata particulară}

Sufletele drepților vor contempla pe Iisus Hristos, îl vor preamări și vor sta în fața Tronulul Său. Drepții vor fi în relație reciprocă cu îngerii. Sufletele păcătoșilor nu vor privi pe Dumnezeu, vor fi în relație cu alte suflete nefericite și cu demonii și vor îndura chinuri. Sfântul Ioan Gură de Aur ne îndeamnă să avem în minte totdeauna să știm că există și rai și iad și nu să aflăm unde este locul acestora ${ }^{18}$. La fel este de important nu când vom muri, ci cum vom muri, cum ne va găsi sfârșitul vieții acesteia în ceasul morții.

\section{Intervenţia celor vii pentru cei răposați din iad}

Totuși, soarta sufletelor din iad poate fi schimbată în bine căci „,cei ce se duc în iadul de după judecata particulară cu o anumită credință, deci fără o atitudine total contrară comuniunii cu Dumnezeu, vor putea ajunge în situatia ca virtualitatea capacității de comuniune prezentă în ei să fie actualizată ”' ${ }^{\prime}$. „Prezența lui Dumnezeu în iad vrea să arate cât de mult a prețuit Dumnezeu libertatea omului, lăsându-l să-și hotărască singur propria lui soartă" ${ }^{\prime 20}$.

Cei care nu vor putea ieși din iad până la judecata universală nu vor mai putea ieși în veci din iad. Acest lucru se bazează, spune părintele Stăniloae,

„pe preștiința lui Dumnezeu, în baza căreia Dumnezeu știe sigur că aceia nu vor răspunde în veci ofertei Lui de iubire, fie pentru că nu vor vrea, fie pentru că și-au creat prin refuzul total al comuniunii din viaţa pământească și din răstimpul între judecata particulară și cea universală

\footnotetext{
${ }^{18}$ S.A Arhanghelov, Misterele vieții viitoare, trad. de prof. Clement I. Bontea, Iași, Edit. Pelerinul, 1997, pp. 55-60.

19Pr. Prof. Dr. Dumitru Stăniloae, op. cit., pp. 260-261.

${ }^{20}$ Pr. Prof. Dr. Dumitru Popescu, op. cit., p. 397.
} 


\section{Iulian NEDELCU}

o astfel de stare. După moarte sunt «neschimbabili»: în bine, cei din rai şi cei din iad, în rău”'21.

Biserica are în exclusivitate membri vii. Aceasta rezultă din faptul că, ,prin rugăciune, cei morţi se află în legătură cu cei dragi de pe pământ, şi că aceştia au nevoie de rugăciunile noastre, de mângâiere şi de ajutor, şi care ca şi noi îşi continuă dezvoltarea sufletească în aşteptarea zilei judecăţii" "22.

Slujba înmormântării este rugătoare și un prilej de manifestare a milei lui Hristos pentru păcatele săvârşite. În acest sens părintele Stăniloae spune: „Toate rugăciunile și cântările de la înmormântare se bazează pe această credință în puterea ce o are Hristos de a ierta la judecată păcatele și pe încredințarea în mila Lui. Judecata lui Hristos constă într-un act de putere de a ierta păcatele"'23.

\section{Concluzii}

Cununa rugăciunii sau a contemplației divine este vederea luminii dumnezeiești, teologhisite de gânditorii isihaști: prin apropierea de Dumnezeu, interiorizându-i numele în rugăciune, întreaga ființă a omului este impresionată de har, iar sufletul și trupul unite contemplă energiile necreate ${ }^{24}$.

\section{${ }^{21}$ Ibidem.}

${ }^{22}$ Fritjof Tito Colliander, Credinţa şi trăirea Ortodoxiei, trad. rom. de Pr. Dan Bădulescu, Bucureşti, Edit. Scara, 2002, p. 36.

${ }^{23}$ Pr. Prof. Dr. Dumitru Stăniloae, op. cit., p. 283.

${ }^{24}$ Cf. Pr. Prof. Dr. Dumitru Stăniloae, Semnificaţia luminii dumnezeieşti, în „Ortodoxia”, an. XXVIII, 1976, nr. 3-4, pp.433-446; cf. John Breck, Sfânta Scriptură în Traditiia Bisericii, trad. Ioana Tămăian, Cluj-Napoca, Edit. Patmos, 2003, pp. 303 s.u. 


\section{Bibliografie}

1. Arhanghelov, S.A, Misterele vieții viitoare, trad. de prof. Clement I. Bontea, Iași, Edit. Pelerinul, 1997.

2. Azkoul, M., The Toll-House Myth. The Neo-Gnosticism of Fr. Seraphim Rose, Dewdney B. C.

3. Breck, John, Sfânta Scriptură în Tradiţia Bisericii, trad. Ioana Tămăian, Cluj-Napoca, Edit. Patmos, 2003.

4. Chiţescu, N., Petruţă I., Isidor Teologia Dogmatică şi Simbolică, Cluj-Napoca, vol. II, ed. a II-a, 2005.

5. Colliander, Fritjof Tito, Credinţa şi trăirea Ortodoxiei, trad. rom. de Pr. Dan Bădulescu, Bucureşti, Edit. Scara, 2002.

6. Constantinescu, Ioan, Rugăciunile pentru cei morţi, în „Glasul Bisericii”, an. XXXIV, 1975, nr. 7-8.

7. Herma, Păstorul, Pilda I, în Scrierile Părinţilor Apostolici, din col. P.S.B., vol. 1.

8. Larchet, Jean Claude, Tradiția ortodoxă despre viața de după moarte, trad. din $\mathrm{lb}$. franceză de Mihaela Bojin, București, Edit. Sophia, 2006.

9. Puhalo, I., The Soul, the Body and the Death, Dewdney, B. C., 1996. The Tale of Elder Basil the New and the Theodora Myth. Study of a Gnostic Document, Dewdney B. C., 1999.

10. Popescu, Dumitru, Iisus Hristos Pantocrator, București, Edit. Institutului Biblic şi de Misiune al Bisericii Ortodoxe Române, 2005.

11. Remete, George, Dogmatica Ortodoxă, Alba-Iulia, Edit. Reîntregirea, 2007.

12. Sf. Ambrozie al Milanului, Scrisori, scrisoarea a LXXVII-a, 11, in PSB, vol. 53.

13. Sf. Ioan Gură de Aur, Omilia despre răbdare și recunoștință, care se citește în cadrul slujbelor Bisericii Ortodoxe în cea de-a şaptea duminică a Paștilor și la slujbele de înmormântare.

14. Sfântul Maxim Mărturisitorul, Invăţătura despre viaţa morală în 170 de capete, în Filocalia, vol. I, traducere de Pr. Stavr. Dr. D. Stăniloae, Sibiu, Tipografia Arhidiecezană, 1947.

15. Sf. Vasile cel Mare, Regulile morale, Reg. 11, în PSB, vol. 18. 
16. Stăniloae, Dumitru, Semnificaţia luminii dumnezeieşti, în „Ortodoxia”, an. XXVIII, 1976, nr. 3-4.

17. Stăniloae, Dumitru, Teologia Dogmatică Ortodoxă, ed. a IIa, vol. III, Bucureşti, Edit. Institutului Biblic şi de Misiune al Bisericii Ortodoxe Române, 1997. 